\title{
Students' Views of the Promoters and Barriers to First Year College Persistence in Ireland: A Partnership Study
}

\author{
Natasha Daniels and Pádraig MacNeela \\ National University of Ireland Galway, Ireland
}

\begin{abstract}
Navigating the transition to college and persisting is crucial to student college success. This research aims to explore the promoters and barriers to first year persistence, the student support needs in relation to these promoters and barriers, who students need the support from and when support is particularly needed. A participatory methodological approach was central to the study, carried out through a partnership with a cohort of 28 second year students to retrospectively explore the first year college experience in Ireland. Participatory workshops conducted with the students identified persistence promoters, including being on the right course, gaining independence, academic supports, and connection to home. Barriers included being on the wrong course, anxiety, and lack of motivation to first-year student persistence. These factors were further developed by the students to identify support solutions, personnel they need support from, and a three-pronged delivery solution, beginning in post-primary school through preparation for the transition to college. While confirming previous international studies, the research adds a novel understanding of the first-year student experience towards persistence and highlights the value and importance of giving students the space to share their original and detailed perspective of first year, as a student perspective supporting solutions for better higher educational outcomes.
\end{abstract}

Keywords: First year; persistence; participatory research; college; transition

\section{Introduction}

Student participation in education is an important matter for students, parents, educators, and policymakers alike. Critically, successful student participation in education is based on continuous persistence. The focus of much research in this area has been on the explanation of student retention, taking the viewpoint of education institutions that pose the question of what they can do to improve retention. However, when students are engaged with on such issues the focus quickly turns to persistence, not retention. Student persistence is defined as a quality that allows a student to continue towards their educational goal even in the face of challenges, a quality closely linked by Vincent Tinto to the motivation to continue (2017). In turn the focus of student success research should be on what colleges can do to influence their students' motivation to stay, persist, and graduate, as this would in turn satisfy the original interest of higher education institutions to retain their students (Tinto, 2017). To achieve this reorientation to a process-based analysis of the student experience, institutions need to work with students to gain knowledge of their experiences and the support needs that enable a successful persistence process. 
In Ireland, a higher proportion of post-primary school students transition to third-level ${ }^{1}$ education than in any other EU country (Department of Education and Skills, 2018). The number of post-primary school students moving onto higher education in Ireland has increased significantly since the 1950s (Redmond, 2000) with 43,500 undergraduate entrants in recent years, amounting to approximately $60 \%$ of post-primary school leavers (Higher Education Authority, 2020). However, of these students $14 \%$, or approximately 6,000, do not persist past their first year annually (Higher Education Authority, 2016), and $63 \%$ of all non-completion is accounted for by students leaving during first year (Higher Education Authority, 2019). Compared with international trends, Ireland is experiencing a moderate level of student non-progression (Heubelin, 2014). Given these statistics, one of the most important priorities for institutions is to support students as they transition to third-level education. This research addresses the issue of first-year student non-progression, exploring the proposition that the process of successful first-year student persistence is founded on protective factors, and contributing to the development of a research methodology involving the lived experiences of students who have already engaged in this process.

There is a wealth of research on student persistence and retention to date (see for example Ketonen, et al., 2015; Larsen et al., 2013; MAP-Works ${ }^{\mathrm{TM}}$; Redmond et al., 2011; Ryan \& Glenn, 2004; Tinto, 2006, 2014, 2017; Yonghong, 2016). This work documents a wide range of personal and institutional factors that impact students' experiences and therefore their persistence and retention in college (Hinton, 2007; Larsen, et al., 2013; Redmond et al, 2011; Sadowski et al., 2018; Tinto, 1993, 2017; Yonghong, 2016). Many studies identify barriers to first-year student persistence, including first generation status (Tinto, 1993), lower family socioeconomic background, (Larsen, et al., 2013), financial strain (Bexley et al., 2013), an unsuitable college course (Redmond et al., 2011;), and a lack of social integration (Hinton, 2007; Redmond et al., 2011; Tinto, 1993), personal motivation (Tinto, 2017), and preparedness for college (Larsen, et al., 2013; Redmond 2011; Sadowski, 2018). In conjunction with this, the factors that promote first-year student persistence and or retention, are well documented, by Vincent Tinto in particular, and include motivation, self-efficacy, the feeling of belonging at the institution (Thomas et al., 2017; Tinto, 2017), strong social connections, high academic ability, formal academic integration (Tinto, 1993). There is widespread agreement that these comprise important factors conducive to a successful process of persistence (Brooker et al., 2017; Hinton, 2007; Larsen et al., 2013; Lowe \& Cook, 2003; MAP-Works ${ }^{\mathrm{TM}}$, 2014; Redmond et al., 2011).

Previous research agrees that there is no single factor identified to explain student withdrawal prior to programme completion, but more likely there are multiple factors responsible for attrition as suggested by Nelson, Duncan and Clarke (2009). However, while well-developed in some respects, research-based knowledge on risk factors for withdrawal has had little development of information and knowledge derived from students' own experiences and through an affirmative approach that explores successful persistence. Much of the research available has adopted quantitative research methodologies (Ketonen, et al., 2015; MAP-Works ${ }^{\mathrm{TM}}$, 2014; Ryan \& Glenn, 2004; Yonghong, 2016). There is less evidence available from qualitative methodologies (Moore-Cherry et al., 2015; Redmond, et al., 2011; Sadowski, et al., 2018). The research base to-date features researchers alone interpreting and presenting the data, not in partnership with students. The consequence of this is a lack of student-derived insight as co-researchers with input and control over data development and interpretation. This current study offers an alternative perspective by adopting a participatory research methodology that includes the students as participants and partners in the research process and data development. Student generation, analysis, interpretation, and presentation of their own data is a central element of this current research, resulting in a unique contribution to this body of research: What do students who have persisted through first year in college have to say about the factors that influenced persistence, what supports they need, and when they are needed.

One study of significance in identifying a model for working in partnership with students on persistence-related issues was carried out by Sadowski et al., (2018). This Australian study adopted an Action Research approach with a participatory methodology which included a sample of first, second- and third-year students. The study found that students faced challenges in relation to personal circumstances, lack of preparedness for university study, timely access to support, and course difficulties. The associated supports identified by the students related to an academic advisory function, university support services, growing confidence in self as a competent student, and peer support. The current study aims to build on this previous research by conducting participatory research focused on the identification of promoters and barriers to first-year student persistence by enabling second-year students to develop, interpret and present their knowledge of this transitional time from their lived experience towards identifying student supports.

\footnotetext{
${ }^{1}$ Third-level refers to third-stage or post-secondary education, following the completion of secondary education and is also referred to as tertiary education
} 
Participatory research differs from conventional research by focusing on carrying out research with people and not on people (Cornwall \& Jewkes, 1995). Over the past decade there has been a growing emphasis internationally on involving children and young people in research, service design, and decision-making processes (Department of Children and Youth Affairs, 2019; O'Hara, et al., 2017) on matters that affect their lives. It is widely acknowledged that young people are skilled decision-makers, able to reflect upon and shape their own experiences and environments (Lundy, 2007). It is a notable gap that this type of research approach is less developed in educational settings compared with community work (Wallerstein, et al., 2006), health services (Domecq, et al., 2014), or youth work (National Youth Council of Ireland, 2018). Participatory research methodology, which can incorporate varying degrees of participation due to research circumstances (Hart, 1992), at its best provides participants with increased control over the research, giving the opportunity to share their views and opinions without researcher interpretation and have them listened to (O'Higgins \& Nic Gabhainn, 2010). This is the ethos and aspiration for this current study. By drawing on the experiences of students in this study, knowledge and supports concerning persistence in first year are more likely to reflect the lives of students and their direct needs for specific interventions.

The use of a partnership approach with students is novel, due to their involvement in guiding both the research project overall, as well as participating in data generation, analysis, and interpretation. This approach was adopted to explore students' perspective of first year college persistence towards developing student support solutions in Ireland. The purpose was to utilise a methodology that situated students central to the research processes, and enabled them to generate, analyse, interpret, and present the data in relation to the first year college experience and how students can be supported to persist. A central objective of this study was to develop a Student Research Partnership Panel (SRPP), composed of second-year students to work as part of the research team developing, implementing, and participating in the research. The aim was for these students to retrospectively examine their first year experience towards identifying supports needed to promote first-year student persistence utilising an affirmative approach. To achieve this, the study had four research questions:

1. From the student's perspective, what are the promoters and barriers to student persistence experienced by first-year students?

2. From the student's perspective, what supports do first-year students need and who do they need this support from?

3. When during first year of college do students need these identified supports?

4. Can students participate as research partners towards finding a solution to the student-centred issue of persistence?

\section{Methodology}

\section{Study Design}

This study adopted a participatory research methodology with the aim of student involvement in the entire research process. Participatory research often involves the fitting of research principles to design a unique methodological approach that addresses the research questions. Hart (1992) identified the distinguishing features of participatory research to include research carried out by or with the people concerned, the presence of a commitment from the researcher to the participants and their control of the analysis, and for the research to investigate the underlying causes of the problem so the participants can begin addressing it. In addition to meeting the criteria identified by Hart, the approach of this current study is also derived from the four principles of Lundy's (2017) conceptual participation model through the provision of a space, a voice, influence, and an audience for the students. With these in mind, a methodology implementation plan was designed with two stages, outlined in Table 1 below. 
Table 1

Stages of the Participatory Methodology

\begin{tabular}{|l|l|l|}
\hline & Stage 1 & Stage 2 \\
\hline Aim of the stage & $\begin{array}{l}\text { Development and implementation of the } \\
\text { SRPP. }\end{array}$ & $\begin{array}{l}\text { Implementation of student participatory } \\
\text { workshops. }\end{array}$ \\
\hline Approach taken & $\begin{array}{l}\text { Student panel members act as partners in the } \\
\text { research. Involvement includes study protocol } \\
\text { development, student recruitment, data } \\
\text { analysis and presentation. }\end{array}$ & $\begin{array}{l}\text { Larger group of students participating in two } \\
\text { linked workshops developing and analysing } \\
\text { their data towards the articulation of the student } \\
\text { perspective. }\end{array}$ \\
\hline Adapted from & $\begin{array}{l}\text { Jigsaw Ireland } \\
\text { (an Irish Youth Mental Health Organisation; } \\
\text { Illback, et al., 2010) }\end{array}$ & $\begin{array}{l}\text { Daniels et al., 2014; INVOLVE, 2016; } \\
\text { Olufisayo John-Akinola et al., 2014; O'Higgins } \\
\text { \& Nic Gabhainn., 2010. }\end{array}$ \\
\hline
\end{tabular}

One benefit of involving young people in participatory research is securing their input to identify appropriate methodologies that are acceptable to their peers, including creative and innovative ways of collecting data (Shaw et al., 2011). This approach has been utilised in this current study and the methodologies that are applied are drawn from specific exemplars used in previous research (Daniels et al., 2014; Illback, et al., 2010; Olufisayo John-Akinola et al., 2014; O’Higgins \& Nic Gabhainn., 2010). Implemented together, the two stages used in the participatory research approach offered the students an opportunity to be active citizens, in keeping with national and international youth engagement goals (Department of Children \& Youth Affairs, 2015), promoting a strengths-based stance on addressing student education attainment problems by identifying opportunities that could enhance the process of persistence.

The application of this methodology is best explained in three interlinked phases. The first phase involved the establishment of the SRPP as partners in the research process. The second phase focused on recruitment of a wider student pool and their participation in group data collection workshops. The workshops involved each group of students participating in two data generation and analyses sessions. The final phase of the research involved the SRPP reviewing the data produced from all group workshops, identifying themes, and presenting the "data story" for the overall project. Ethical approval for this research was granted by the Research Ethics Committee of the National University of Ireland Galway. The overall research question of the study was established prior to commencing work with the students. The panel involvement began after ethical approval, involving the panel members reviewing the overall study idea, research questions, the best way to ask the questions of the other students, the workshop protocols, and methodologies. In addition to this, the help and participation of the SRPP summarising and presenting the data for this paper upholds their right to a voice to share their opinions and perspectives with an audience. Separately the findings of their research were shared with the management of the education institution where this research was conducted to ensure the audience has due influence to act upon the research findings, in keeping with the four principles of Lundy's model of participation (2017).

\section{Phase 1 - Student Research Partnership Panel Recruitment and Procedures}

The SRPP project was advertised using a variety of online and word-of-mouth channels on campus. Four students volunteered to participate, which comprised a manageable group size for the process of planned work. The panel comprised three females and one male, ranging in age from 19 to 47 years (three participants were aged under 23 years). All were second year students. Three of the students were representative of a "youth" age range (15 to 24 years), with the addition of one mature second year student who expressed a keen interest in participating in the project. Each student participant was awarded ECT credits (predefined credits assigned based on defined learning outcomes and their associated workload), for their participation in the project and a voucher to acknowledge their contribution when the project ended. 
Once the SRPP was established, the researcher and the panel arranged a meeting to discuss the project in more detail. The panel met with the researcher on four occasions throughout the duration of the project and all four members attended each meeting/workshop. The duties of the panel were discussed and agreed upon during the first meeting. These included: Reviewing the drafted research questions and the data collection workshop methodologies, participation in the workshops to gain an indepth understanding of the process, helping with student recruitment for the workshops, and contributing to the review, analy sis and clear presentation of the findings of the student-generated data. The students were assured of the value of their opinions and input and were asked to be open and honest during the process. If the students did not agree with any part of the research, they expressed this, and a change or solution was agreed upon by the students. meeting 2 and 3 were for the SRPP to participate in the workshops and meeting 4 was for the Panel to review all the student data and develop their data story.

\section{Phase 2 - Student Group Workshops Recruitment and Procedures}

Second year students were contacted via various campus groups and recruited. Some students who participated were eligible to receive class credit for research participation. It was not part of the project development, planning, or ethical approval to include students who had not persisted. It was the aim of the study to work with students who had completed first year and therefore had the lived experience and hindsight to consider the year in its entirety and to develop data on the support needs of first-year students who had persisted. The research process involved participation in two consecutive workshops. These workshops were carried out in the northern hemisphere Spring 2018 with 28 second year college students.

Workshop 1 provided students with a "blank canvas" to explore the promoters and barriers of first year college persistence. The aim of this workshop was for the students to share their ideas about this in an open-ended process without any influencing materials other than the research questions. In workshop 2, using the data generated in workshop 1, the participants developed a "Timeline of Supports" for the first year of college. The two workshops were run for four groups of students who volunteered to participate, achieving the originally agreed approximate participant number of 30 participants (Guest et al., 2017). The participants were randomly assigned to each workshop group based on the order in which students volunteered. The students were primarily from the College of Arts, Social Sciences, and Celtic Studies $(n=25)$, Biomedical Science $(n=4)$, Law ( $n=1)$, and Business $(n=4)$. The workshops were piloted with a group of six second year students and all students were able to participate fully, without need for subsequent adaptation or changes. Due to this, the data from this group were included in the main study.

\section{Workshop 1 Procedure}

During this workshop, the student activities were guided to answer each of the following four research questions:

1. What promotes student persistence during first year at college?

2. What prevents student persistence during first year at college?

3. What supports are needed to help students persist during first year at college?

4. Who is this support needed from?

The workshop took place through four activities:

Data generation promoters and barriers: Each participant was given Post-Its and asked to write one answer in response to "what are the promoters to student persistence during first year in college?" then all Post-Its were placed on a display space. Secondly, they were asked to do the same for the question; "what are the barriers to student persistence during first year in college?" and these Post-Its were placed in a separate designated space. This was an individual activity carried out in a quiet space.

Data categorising: This was a group activity completed separately for the promoter data and barrier data. To help with this activity the researcher acted as a non-directive facilitator to the process moving the Post-Its into groupings as directed.

Voting: This was an individual activity. Each participant was given five votes to identify their top promoters and five more votes to identify their top barriers to student persistence. The votes were counted and the top barriers and promoters to student persistence were identified. 
Pizza chart generation: The participants were divided into two groups, one of which worked on the barrier themes while the other group worked on the promoter themes. Each group was given a pre-prepared chart with the top barriers or promoters written into the centre layer of the chart and were asked to complete the two remaining layers by answering the following: Identify the actions/supports students need to address the barrier/promoter? And Identify who needs to be involved in this process?

\section{Workshop 2 Procedure}

Preparation: During the week between workshop 1 and workshop 2 the researcher prepared materials to support an engaging structure for workshop 2 that provided suitable opportunities for participation. This involved blank timeline charts and a "pack of cards" with each individual support identified in workshop 1 written on an individual card.

The card game: The participants worked in small groups with a "pack of cards" and a timeline chart. The group was asked to deal the cards and to decide what part(s) of the timeline the support belonged in. Participants were provided with glue to stick the support on and colours to identify how long the support is required along the timeline.

Timeline review: When each group completed their timeline, they were asked to review it and add any additional supports they thought were important in red marker to help differentiate them.

\section{Phase 3 - Data Storytelling}

The final researcher and SRPP meeting aimed to review the pizza chart data from all the workshops and to tell the overall "data story". This meeting had four central aims, to identify:

1. The key barriers to persistence during first year in college.

2. The key promoters to persistence during first year in college.

3. Who were the primary sources of help/support identified by the students?

4. The key supports students need and when they need them during year one at college.

The activities undertaken in this final meeting were mapped to the aims. The first activity involved the SRPP reviewing the barriers data. The panel reviewed this data by using a colour coding system where all barriers were categorised into related themes. For example, all themes related to "course" were red, "friends" were blue, and so on, until all related themes were merged resulting in the key barriers. This activity was repeated for "promoters", "supports" and "who". This data collection and analysis approach adopts a similar ethos to previous participatory research (Daniels et al., 2014; INVOLVE, 2016; O'Higgins \& Nic Gabhainn, 2010). The use of such interactive and inclusive research activities during this type of research is well documented and regarded (Illback, et al., 2010; INVOLVE, 2016) and this current study adds to the literature on the utility and usefulness of this methodological approach.

\section{Results}

The results are presented in two sections to represent the stages of the research. Phase 1 presents the decisions, procedural agreements and changes made by the SRPP before group data collection begun. Phase 2 presents the results of the group data collection phase and the interpretation of the SRPP of these data overall, the "data story".

\section{Phase 1 -SRPP Meeting 1 Outcomes}

During meeting 1 the SRPP reviewed the research questions and the workshop methodologies as devised for ethical approval. For workshop 1 the panel agreed that the research questions should be asked in a simplified way. They agreed to keep the original research question during the workshops, namely "what are the promoters to student persistence during first year in college?" and decided to display the question phrased in three different ways with the addition of two reworded versions: "what positive thing did you experience to help you stay in college?" and "what positive thing did you experience to help you stick out first year?" The barriers research question was rephrased in a similar way. 
For workshop 2 the panel identified six parts of the academic year to divide the timeline into to enabling the students identify when they need supports. The six parts that were identified as important to be individually considered were: before entering college, the first four weeks of college, the rest of semester one, Christmas exam time, semester two, and Summer exam time.

\section{Phase 2 - Data Generation and the "Data Story"}

\section{The Promoters}

In total the participants developed 136 individual responses when identifying promoters. The participants categorised these individual data into 30 themes of promoters. The SRPP reviewed the 30 themes during the final SRPP workshop and using a colour coding system identified six key promoters emerging from the workshops as displayed in Table 2.

\section{Table 2}

The Six Key Promoters to First-year Student Persistence

\begin{tabular}{|c|c|c|c|}
\hline Student Group 1 & Student Group 2 & Student Group 3 & Student Group 4 \\
\hline Course & Course & Course & Course \\
\hline Social life/friends & Social life/friends & Social life/friends & Social life/friends \\
\hline Independence & Independence & Independence & Independence \\
\hline Academic & Academic supports/ & Academic supports/ & \\
\hline experiences & Home \\
\hline Home & Home & Galway & Galway \\
\hline
\end{tabular}

Within each of these six key promoters to student persistence, the participants identified what specific supports they need to enact them and who they need the support from. Table 3 details this information for three promoters that emerged in at least three group workshops. The "who" data displayed in Table 3 represents the people or services the students deemed relevant to be involved in addressing the supports generally in relation to each promoter.

Table 3

What Supports Students Need to Persist and Who They Need This Support From

\begin{tabular}{|c|c|c|}
\hline $\begin{array}{l}\text { Promoter } \\
\text { Category }\end{array}$ & What supports are needed to enact this promoter? & From whom? \\
\hline Course & $\begin{array}{l}\text { Options for transferring (x3). } \\
\text { Make course assessments clearer (x2). } \\
\text { Emphasis balanced on Leaving Certificate and college in school } \\
\text { (x2). } \\
\text { Promotion of facilities e.g., guidance counsellor. } \\
\text { Longer fresher's week for first-years students. }\end{array}$ & $\begin{array}{l}\text { Class representatives. } \\
\text { First-year coordinator. } \\
\text { Guidance counsellors in school. } \\
\text { Guidance counsellors in college. }\end{array}$ \\
\hline Independence & $\begin{array}{l}\text { Helping students with life skills like cooking, budgeting etc. } \\
(\mathrm{x} 2) \text {. } \\
\text { Being away from home/parents for the first time. }\end{array}$ & $\begin{array}{l}\text { Students Union. } \\
\text { Clubs and societies. } \\
\text { Parents. }\end{array}$ \\
\hline Social life/friends & $\begin{array}{l}\text { Clubs and societies are important }(\mathrm{x} 3) \text {. } \\
\text { Student accommodation integration }(\mathrm{x} 4) \text {. } \\
\text { More fun days and events for classes (x2). } \\
\text { Smaller classes sizes (x2). } \\
\text { Emphasis should be made in class to engage in the people beside } \\
\text { you - not enough encouragement (x2). }\end{array}$ & $\begin{array}{l}\text { Lecturers (x3). } \\
\text { Mentors (x2). } \\
\text { Students Union. } \\
\text { Friends. } \\
\text { Course co-ordinator. } \\
\text { Accommodation office. } \\
\text { Societies and clubs. }\end{array}$ \\
\hline
\end{tabular}

Notes: *** (x2) stated in 2 separate workshops. (x3) stated in 3 separate workshop groups. 


\section{The Barriers}

In total the participants developed 132 individual responses when identifying barriers. The participants categorised these individual data into 23 themes of barriers. The SRPP reviewed these 23 themes during the final SRPP workshop. Using a colour coding system, the group identified ten key barriers as emerging from the workshops, displayed in Table 4 below.

Table 4

The Ten Key Barriers to First-Year Student Persistence

\begin{tabular}{|c|c|c|c|}
\hline Student Group 1 & Student Group 2 & Student Group 3 & Student Group 4 \\
\hline & Course & Course & Course \\
\hline Friends/loneliness & Money & Friends/loneliness & Friends/loneliness \\
\hline & & Money & Money \\
\hline Accommodation & & Accommodation & Accommodation \\
\hline Adapting to college & Academic stress & Academic stress & \\
\hline Academic stress & & & \\
\hline Anxiety & Lack of Motivation & & \\
\hline Academic skills & & & \\
\hline & & & Substance abuse \\
\hline
\end{tabular}

The participating students provided insight into the specific supports needed to reduce or eliminate each of the 10 barriers to persistence that were identified. Table 5 details this information for three barriers that emerged in at least three group workshops. The "who" data displayed in Table 5 represents the people or services the students deemed relevant to be involved in addressing the supports generally in relation to each barrier.

\section{Table 5}

What Supports Students Need to Persist and Who They Need This Support From

\begin{tabular}{|c|c|c|}
\hline $\begin{array}{l}\text { Barrier } \\
\text { Category }\end{array}$ & What supports are needed to reduce/eliminate this barrier? & From whom? \\
\hline Course & $\begin{array}{l}\text { More information on open days }(\mathrm{x} 2) \text {. } \\
\text { Options for transferring }(\mathrm{x} 2) \text {. } \\
\text { Meetings with academic supervisors more accessible. } \\
\text { Promoting college facilities, e.g., guidance counsellor. } \\
\text { More information on modules. }\end{array}$ & $\begin{array}{l}\text { Course directors (x2) } \\
\text { First-year co-ordinator. } \\
\text { Guidance counsellors in school. } \\
\text { Guidance counsellors in college. }\end{array}$ \\
\hline $\begin{array}{l}\text { Friends/ } \\
\text { Loneliness }\end{array}$ & $\begin{array}{l}\text { Joining clubs and societies (x2). } \\
\text { Tutorials and smaller class sizes (x2). } \\
\text { Talking to a counsellor. } \\
\text { More promotion of mental health supports. } \\
\text { Semester } 2 \text { orientation. } \\
\text { Ongoing efforts to help students to get to know others. }\end{array}$ & $\begin{array}{l}\text { Clubs and societies }(\mathrm{x} 2) \\
\text { Accommodation }(\mathrm{x} 3) \\
\text { Course co-ordinator. } \\
\text { Mentors. } \\
\text { Lecturers/head of schools. }\end{array}$ \\
\hline $\begin{array}{l}\text { Adapting to } \\
\text { college/ new } \\
\text { experiences }\end{array}$ & $\begin{array}{l}\text { Friends are so important. } \\
\text { Tutorials and tutors can help. } \\
\text { Longer orientation. } \\
\text { More first year events. } \\
\text { Map - more awareness of interactive map online. }\end{array}$ & $\begin{array}{l}\text { Tutors. } \\
\text { Mentors. } \\
\text { Friends. } \\
\text { Student union. } \\
\text { Co-ordinators. }\end{array}$ \\
\hline
\end{tabular}


Table 6

Summary of the Number of Supports Needed During First Year at College with Examples

\begin{tabular}{|l|c|l|}
\hline $\begin{array}{l}\text { Part of the } \\
\text { Academic Year }\end{array}$ & $\begin{array}{l}\text { Number of } \\
\text { Supports } \\
\text { needed }\end{array}$ & \multicolumn{1}{|l|}{ Examples of specific supports } \\
\hline $\begin{array}{l}\text { Before entering } \\
\text { college }\end{array}$ & 47 & $\begin{array}{l}\text { Not enough supports in secondary school for students to transition to college } \\
\text { life. } \\
\text { More supports from schools and guidance counsellors. }\end{array}$ \\
\hline $\begin{array}{l}\text { First four weeks of } \\
\text { college }\end{array}$ & 44 & $\begin{array}{l}\text { Longer fresher's week for first-year students to get to know the place. } \\
\text { More options for transferring. } \\
\text { Better assignment to accommodation. }\end{array}$ \\
\hline Semester one & 28 & $\begin{array}{l}\text { Opportunity to switch accommodation during the year. } \\
\text { More interactive classes. } \\
\text { Group projects/tutorials. }\end{array}$ \\
\hline Christmas exam time & 11 & $\begin{array}{l}\text { Longer time before exams to study. } \\
\text { Time management courses. }\end{array}$ \\
\hline Semester two & 18 & $\begin{array}{l}\text { Lecturers' office hours. } \\
\text { Promoting clubs and societies. } \\
\text { Semester two orientation. } \\
\text { More leeway to change course without having to pay full fees again. }\end{array}$ \\
\hline Summer exam time & 4 & Longer time before exams to study. \\
\hline All year supports & 63 & $\begin{array}{l}\text { More promotion of mental health supports. } \\
\text { More leeway to change course without having to pay full fees again. } \\
\text { Stricter requirements for attendance. }\end{array}$ \\
\hline
\end{tabular}

\section{Workshop 2 Timeline of Supports}

Six support timelines were created based on the support information from workshop one. Table 6 aligns the supports with each part of the year and provides examples of the supports. In addition to this, the SRPP reviewed the "Timeline of Support" data and developed an overview of the data. This overview details the main overarching concept of three key stages of first year in college and the primary areas to focus support in each one (Table 7).

Table 7

Overview of the Timeline of Supports Data

\begin{tabular}{|l|l|l|}
\hline Part of the academic year & Overall concept & Overview points \\
\hline Before entering college & "Being prepared" & $\begin{array}{l}\text { Selecting the right course. } \\
\text { Figuring out your strengths in school. } \\
\text { Knowing what to expect in general. } \\
\text { Accommodation. }\end{array}$ \\
\hline Semester 1 & "Settling in" & $\begin{array}{l}\text { Time management skills. } \\
\text { Academic support, grinds, and tutorials. } \\
\text { Transferring course options. } \\
\text { Online group chat within each course for social } \\
\text { support. }\end{array}$ \\
\hline Semester 2 & & $\begin{array}{l}\text { Stricter attendance linked to credits. } \\
\text { More continuous assessment. } \\
\text { More tutorials and grinds. } \\
\text { Emphasis on club and society involvement. } \\
\text { Condensed timetable - not hanging around. }\end{array}$ \\
\hline
\end{tabular}


Figure 1 integrates the findings from the detailed student workshops. Inspired by the analogy of 'college ecology', this representation enables the priority promoters and barriers to first-year student persistence to be identified. It also allows inclusion of people and services who the students identified as providers of supports related to the identified promoters and barriers. Lastly a three-pronged delivery approach and themes for the supports is identified.

\section{Figure 1}

\section{Summary of the Student Data}

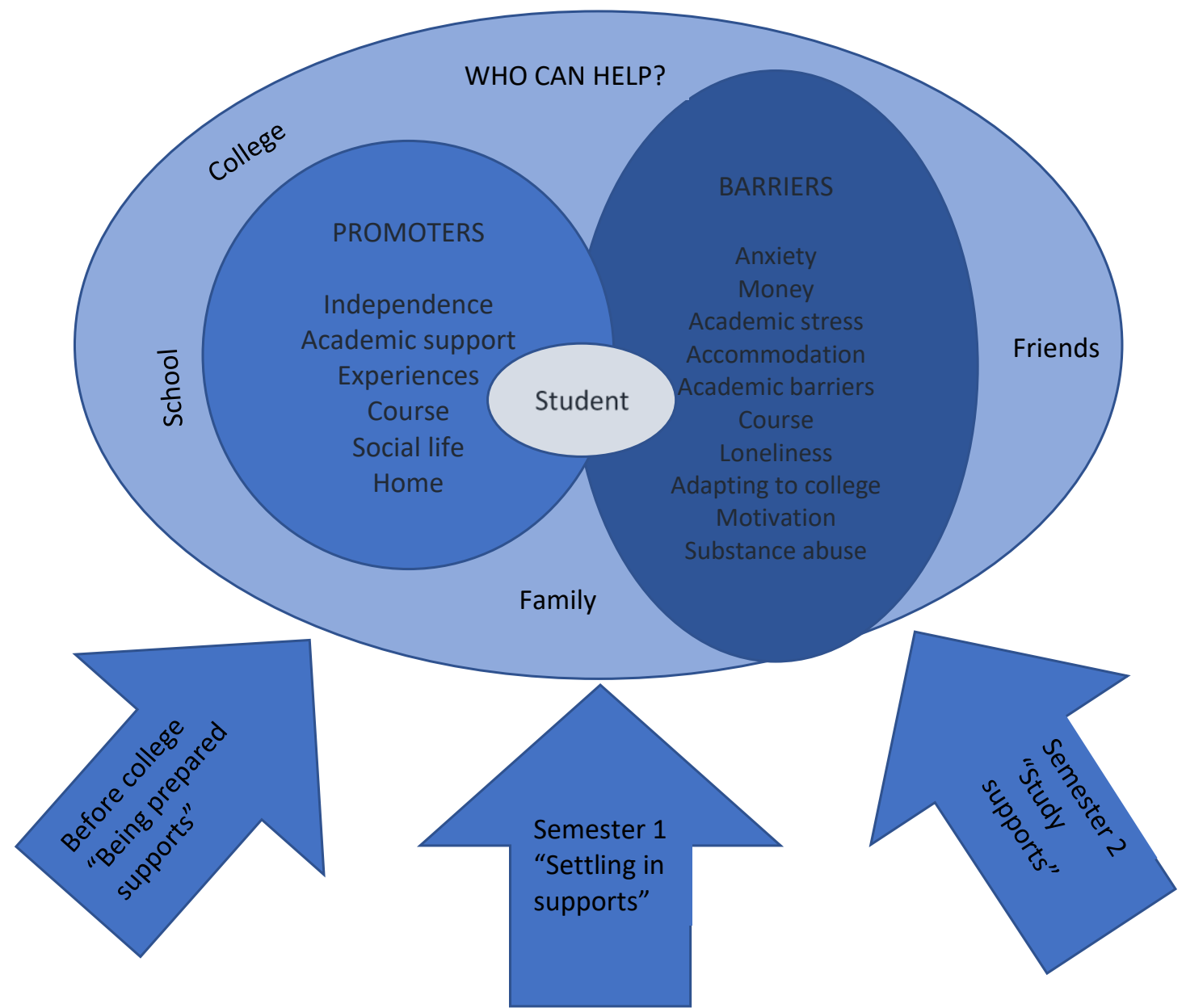

\section{Discussion}

The focus of this research was to involve students as research partners towards identifying student persistence support solutions. Although situated within an Irish context, it can be argued that the findings have relevance for other countries given the identification in this study of factors seen in previous research. The study represents the use of a novel methodology with students partnering in a research project to explore student persistence and present their unique viewpoint, thereby adding a valuable perspective and methodological approach to student persistence literature. This demonstrates their ability and knowledge to participate in solution focused projects and or research with education institutions towards student persistence solutions. The students co-designed a practical and applied depiction of persistence for first-year students. They actively participated to generate, theme, categorise and present comprehensive student persistence data in a meaningful way. The students developed data on the promoters and barriers to first year persistence, highlighting student social interactions, personal and time management, academic supports, course transfer options and preparation for college as the key areas. The students 
identified specific supports in relation to these issues, which they felt would enable the promoters and reduce the barriers. They also identified when they need these during the first year in college and who they need support from.

To persist through first year in college, students identified that it is necessary to successfully engage in a complex, ongoing and varying process of interactions and experiences. This echoes previous research (Ketonen, et al., 2015; Nelson et al., 2009; Redmond, et al., 2011). However, in recognition of this the students agreed a highly contextual depiction of key promoter and barriers to first-year students' persistence, through a transparent process of categorising and voting. Six priority promoters emerged from this current research, three of which have been identified in previous research; the "right course" (Redmond et al., 2011), "social life/friends" (Hinton, 2007; Redmond et al., 2011; Tinto, 1993), and "academic supports" concurring with the importance of academic integration identified in previous research (Tinto, 1993). In addition, three new promoters were generated from this current research. "Home" referred to the ability of students to connect with and go home regularly as a source of support, "Galway" describes being part of a new city community which is relevant for students who moved location from rural living to begin college, and "independence" developed as a new promoter from this student-centred research.

Six priority barriers were also decided upon by the students. Being on the wrong academic course, a theme that is reflected in previous research (Redmond, 2011) and "friends"/ "loneliness" in line with the importance placed on social integration at college for student persistence (Tinto, 1993). In addition, "money", "academic stress", and "accommodation" were decided as priority barriers in line with their acknowledgement as important factors for the student experience and thus, persistence in previous research (Brooker et al., 2017; MAP-Works ${ }^{\mathrm{TM}}$ 2014). The students identified difficulty "adapting to college life" as a barrier, which can be linked with the knowledge from the literature that student preparedness and or readiness for college are important to the process of student persistence (Jansen \& van der Meer, 2011).

The findings on promoters and barriers to college strengthen existing literature and emerge as priorities from the students themselves and add new priority areas. Taken together, they represent the key areas identified in this study to focus first-year student supports towards persistence, derived from the students' own lived experiences and perspective. The emergence of three new promoters in this current study also speaks to the importance of an affirmative, prevention-focused approach to generating knowledge on the student persistence process and demonstrates the scope to further develop our understanding of the student experience to-date.

Three promoters and barriers overlap in this study, namely "academic course" (both a promoter and a barrier), "social support" (promoter) or "loneliness" (barrier), and "academic support" (promoter) or "academic stress" (barrier). This convergence places extra weight on these three factors, highlighting their potential to help or hinder a student's persistence. Choosing the right academic course is also referred to in the literature as a key persistence factor by students (Redmond et al., 2011; Sadowski et al., 2018), however this is not specifically addressed within commonly cited models of student retention (Bean \& Eaton, 2002; Tinto, 2006). This current study adds considerable weight to the importance of each student feeling they are in the right course as a key influencing factor and suggests inclusion as a core determinant of student persistence. Academic and social integration are well documented to be key determinants of student persistence (Tinto, 2006; 2017), with this study adding to this knowledge with a perspective directly derived from the students' experience. The identification of "independence" as a promoter and of problems "adapting to college life" as a barrier are linked. Both themes concern the learning of life skills and greater ability to be responsible for oneself as solutions.

Another solution suggested by the students that reoccurred repeatedly was for longer first year orientation, to include aspects of personal development and life skills. This is in line with research on orientation stating that high quality orientation programs can improve retention (Ramsburg, 2007). Although participation in orientation programmes has been shown to be important in helping students adapt to university life (Gill et al., 2011), one of the main criticisms made of these programmes is the potential to overload students with information (Singer, 2003). Building in a longer timeline and greater exploration space to receive and understand this information is a possible solution as suggested by the students in this current study. The emergence of these themes highlights the need for students to be supported academically, as well as personally, in line with previous research (Ryan \& Glenn, 2004; Redmond, 2011, Sadowski, et al., 2018) as they prepare to move to a more independent life stage with greater responsibility.

In addition, the students offered many practical support solutions towards implementing the promoters and eliminating or reducing the impact of barriers. For example, some suggested solutions to the promoter and barrier facets of the academic 
programme itself included "options for transferring", "make course assessments/expectations clearer", and provide "more information on modules". These are practical solutions building upon previous qualitative research where students identified academic course or modules as important to persistence (Redmond et al., 2011; Sadowski, et al., 2018).

In relation to the promoter "independence" the students were able to be specific with the suggested solutions "helping students with life skills like cooking, budgeting etc.". The promoter "friends" and the barrier "loneliness" offered solutions that complement and mirror each other, for instance "clubs and societies are important", "student accommodation integration", "smaller class sizes", "semester two orientation", and "talking to a counsellor". This data builds upon previous research discussing and identifying student persistence challenges (Booker et al., 2017; Ketonen, et al., 2015; Moore-Cherry et al., 2015; Redmond et al., 2011; Sadowski et al., 2018). This study builds on that work through the provision of insights into the students' perspective of the transition to college, their practical approach towards developing solutions, and suggestions on how to improve the student experience and the college environment. The problem-solving orientation of this research and the inclusion of students' perspectives in a holistic way adds a valuable perspective. The identification of support solutions specifically linked to both promoters and barriers of persisitence within one piece of research allows for consideration and consolidation of this student information in a new way, enabling promoters and barriers and their applied solutions to be linked within the timeline of the first year of college.

The students also explored who they needed support from, in terms of personnel or services. Two key observations emerged from this part of the research. Firstly, the students identified many institutional services and personnel that need to be involved in enacting the promoters and eliminating the barriers of student persistence. This highlights their understanding of the complexity of the support required and the collaborative approach needed to improve student persistence. This perspective is consistent with adopting an institutional approach to student success spanning the literature (Thomas, et al., 2017; Tinto, 2006). The second observation is the omission of students as a group of people with the power to improve student persistence. The "who" named included schools, parents, guidance counsellors, college management, lecturers, friends, students union, accommodation office, course coordinators, and Government agencies all having some input or control. Students did not list themselves as agents of change. This could be interpreted to mean that they see students as having little control over their own education and how it progresses. This adds a potentially original finding to the research to date, due to the identification of "timely access to campus supports" by students as important to persistence in previous research (Sadowski, et al., 2018).

This finding highlights a need for student supports during first year and in preparation for the transition to college to be inclusive of Positive Youth Development (PYD) (Lerner et al., 2005) strategies to prepare them to be self-regulating and autonomous for this next life stage. PYD includes a focus on building competence, character (inclusive of developing autonomy), connection, confidence, and compassion. The PYD perspective has the goal of each youth developing their contribution to their own self, their family, community and to society more broadly. This personal development approach is applicable to the transition to college due to the increased independence and self-responsibility students experience. Building on this, a university-wide shift in student inclusiveness in information sharing and decision making is needed. An example of a project that has the potential to help guide universities to increase and promote greater student involvement is the Student Voice Australia Pilot Project. This project has a central aim to build student input into university governance, as an input towards a more systemically inclusive student voice in decision-making and Australian universities (Varnham et al., 2018). The project resulted in the development of a set of principles for quality enhancement across the sector, with student engagement a key focus (Varnham, et al., 2018). Though this project does not specifically focus on student persistence it provides a comprehensive example of engaging greater student participation for enhancing university governance. The pilot project demonstrates the potential for student engagement approaches to be useful in understanding the university experience from students' perspectives, towards an overall college experience reflective of their perspectives and needs.

Although many of the student supports that emerged in this current study are identified in previous research (Brooker et al., 2017; Ketonen et al., 2015; Moore-Cherry et al., 2015; Sadowski et al., 2018), this current study builds on available knowledge through the organisation of the student suggested support provision by time during first year at college. This process involved separating the first year of college into three parts from the student's perspective. Assimilating this perspective could enable higher education institutions to design and tailor first year preparation, orientation, adjustment, and personal development initiatives, with the goal of addressing what students identify they need and when they need it. The novel timeline of supports developed by the students allowed for further exploration of the first year experience and to identify when students needed specific supports. The SRPP overview of this data resulted in three distinct themes. The first theme was named "being prepared" before entering college. This involved each student selecting the right course, securing appropriate accommodation, knowing 
their subject strengths from school, and knowing what to expect from college in general. The second theme was named "settling in" and referred to semester one at college. This involved students' awareness of options to transfer academic programme, to access academic supports and tutorials, to access personal development support (e.g., time management) and opportunities for social interaction (e.g., online group chat within each course for social support). The third theme was named "study supports" and was identified as semester two at college. This involved stricter class attendance linked to credits, more continuous assessment, more tutorials and grinds, and an emphasis on club and society involvement.

\section{Limitations}

The sample size utilised was reflective of other participatory research, and thus remained relatively limited due to the commitment and time involved in repeated engagement with participants and the process of engaging them with tasks and discussion of shared perspectives. While it is a limitation that the study does not offer a focus on more specific student demographic groups, the nature of the methodology lends itself to inclusive participation, particularly of student groups that can be hard to reach. Further research on promoters and barriers of persistence could be carried out in different countries and across different disciplinary areas, and should include the perspectives of non-traditional students, mature students, students with disabilities, international students, and first-generation students. Such further development of the student participation methodology used in this study would be complementary to the exploratory nature of this research aiming to portray a more general sense of the first-year student experience.

The inclusion of one mature student within the student panel could be interpreted as a possible limitation, however this student expressed a great interest in participating in the project and was excited to be involved in such a practical work happening on campus with potential positive implications for the students. The self-selection process of the students who participated may be considered a limitation due to the possibility that more enthusiastic students participated thus further research, and a larger number of student groups, would be beneficial to ensure important data is not being missed. This study focuses on the promoters and barriers of first year persistence with second year students, however it would be important to hear the opinions of students who did not progress with their studies in terms of the barriers they experienced, when in the timeline and supports that may have helped them overcome these. This study was not developed based on a guiding theory due to the focus of the research on students developing and presenting their data from their perspective. The researchers prioritised giving the participants the "space" to create their own data and to build their own model. However, considering the data developed by the Ecological Model for Health Promotion (McLeroy et al. 2004) as a conceptual and guiding theoretical framework for understanding the first-year student process within the college environment seems like an interesting theory to investigate in future research.

\section{Conclusion}

To our knowledge, this is the first study in Ireland to work specifically with second year college students who have the lived experience of first year at college towards the development of detailed data on their experience inclusive of promoters, barriers, supports and timelines for support towards student persistence. This paper portrays the wealth of important information students have to offer in relation to improving student persistence internationally. In addition, this study also highlights the potential value and benefit of such partnership with students, with the potential for practical applications such as input to university decision-making and governance, given the additional support solutions suggested by students.

The study findings add to the literature on first-year student persistence by validating existing research not conducted with students as partners, and adding new student developed perspectives and solutions. These included more student preparation for college supports, more flexible course selection and transfer options, social supports in semester one specifically, personal development and time management supports and academic supports. Importantly, the study enabled students, for the first time, to identify such needs in conjunction with a timeline for delivering them during the academic year. The ongoing communication and relationship of the students and the researchers enabled this next level data generation into suggested institutional and national actions and strategies for change. Other methodological choices would not have enabled the development of such detailed, student-generated data. The use of such partnership approaches will encourage researchers and university management to engage in a comprehensive suite of student participation processes. This goal has both values-based and practical roots, given the applied importance of understanding the problems that students experience and the mechanisms by which these problems can be addressed and lessened, promoting student persistence and retention. 


\section{References}

Bean, J., \& Eaton, S.B. (2002). The psychology underlying successful retention practices. Journal of College Student Retention, 3(1), 73-89. https://doi.org/10.2190/6R55-4B30-28XG-L8U0

Bexley, E., Daroesman, S., Arkoudis, S., \& James, R. (2013). University student finances in 2012: A study of the financial circumstances of domestic and international students in Australia's universities. https://melbournecshe.unimelb.edu.au/ data/assets/pdf_file/0008/1714715/StudentFinances2012.pdf

Brooker, A., Brooker, S., \& Lawrence, J. (2017). First-year students' perceptions of their difficulties. Student Success, 8(1), 49-62. https://doi.org/10.5204/ssj.v8i1.352

Cornwall, A., \& Jewkes, R. (1995). What is participatory research? Social Science and Medicine, 41(12), 1667 - 1676. https://doi.org/10.1016/0277-9536(95)00127-S

Daniels, N., Kelly, C., Molcho, M., Byrne, M., \& Nic Gabhainn, S. (2014). Investigating active travel to primary school in Ireland. Health Education, 14(6), 501 -515. https://doi.org/10.1108/HE-08-2012-0045

Department of Children and Youth Affairs, (2015). National Strategy on Children and Young People's Participation in Decision-making, 2015-2020. https://www.gov.ie/en/publication/9128db-national-strategy-on-children-and-youngpeoples-participation-in-dec/

Department of Education and Skills, (2018). Education at a glance. 2018 OECD Indicators: A Country Profile for Ireland. Dublin: Government Publications. https://www.education.ie/en/Publications/Statistics/International-StatisticalReports/eag-2018-briefing-note.pdf

Domecq, J.P., Prutsky, G., Elraiyah, T., Wang, Z., Nabhan, M., Shippee, N., Brito, J.P., Boehmer, K., Hasan, R., Firwana, B., Erwin, P., Eton, D., Sloan, J., Montori, V., Asi, N., Abu Dabrh, A.M., Hassan Murad, M. (2014). Patient engagement in research: A systematic review. BMC Health Service Research, 14(89). https://doi.org/10.1186/1472-6963-14-89

Gill, B., Ramjan, L., Koch, J., Dlugon, E., Andrew, S., \& Salamonson, Y. (2011). A standardised orientation program for first-year undergraduate students in the College of Health and Science at UWS. A practice report, The International Journal of the First Year in Higher Education, 2(1), 63-69. https://doi.org/10.5204/intjfyhe.v2i1.48

Guest, G., Namey, E., McKenna, K. (2017). How many focus groups are enough? Building an evidence base for nonprobability sample size. Field Methods, 29(1), 3-22. https://doi.org/10.1177/1525822X16639015

Hart, R. (1992). Children's participation: From tokenism to citizenship. https://www.unicef-irc.org/publications/100childrens-participation-from-tokenism-to-citizenship.html

Heubelin, U. (2014). Student drop-out from German higher education institutions. European Journal of Education, 49(4), 497-513. https://doi.org/10.1111/ejed.12097

Higher Education Authority (2016). A study of progression in Higher Education 2012/2013 2013/2014. Dublin: Higher Education Authority. https://hea.ie/assets/uploads/2017/06/A-Study-Of-Progression-in-Irish-Higher-Education-201213201314.pdf

Higher Education Authority, (2018). Key facts and figures; Higher Education 2016/2017. https://hea.ie/assets/uploads/2018/02/HEA-Key-Facts-And-Figures-2016-17-FINAL.pdf

Higher Education Authority (2020). A study of progression in Higher Education 2015/2016 2016/2017. Dublin: Higher Education Authority. https://hea.ie/assets/uploads/2020/10/Progression-Report-October-2020-Final-301020.pdf

Hinton, L. (2007). Causes of attrition in first year courses in science foundation courses and recommendations for intervention. Studies in Learning, Evaluation, Innovation and Development, 4(2), 13-26.

Illback, R.J., Bates, T., Hodgens, C., Galligan, K., Smith, P., Sanders, D., \& Dooley, B. (2010). Jigsaw: Engaging communities in the development and implementation of youth mental health services and supports in the Republic of Ireland. Journal of Mental Health, 19(5), 422-435. https://doi.org/10.3109/09638231003728141

INVOLVE (2016). Involving children and young people in research: Top tips and essential key issues for researchers. https://www.invo.org.uk/wp-content/uploads/2016/01/involvingcyp-tips-keyissues-January2016.pdf

Jansen, E., \& van der Meer, J. (2011). Ready for university? A cross-national study of students' perceived preparedness for university. The Australian Educational Researcher, 39, 1-16. https://doi.org/10.1007/s13384-011-0044-6

Ketonen, E., Haarala-Muhonen, A., Hirsto, L., Hanninen, J., Wahala, K., Lonka, K. (2015). Am I in the right place? Academic engagement and study success during the first year at university. Learning and Individual Differences, 51, 141 - 148. https://doi.org/10.1016/j.lindif.2016.08.017

Lowe, H., \& Cook, A. (2003) Mind the Gap: Are students prepared for higher education? Journal of Further and Higher Education, 27(1), 53-76. https://doi.org/10.1080/03098770305629

Larsen, M., Sommersel, H., Larsen, M. (2013). Evidence of dropout phenomenon at university. Danish Clearinghouse for Educational Research.

https://edu.au.dk/fileadmin/edu/Udgivelser/Clearinghouse/Review/Evidence_on_dropout_from_universities_brief_versio n.pdf

Lerner, R.M., Lerner, J.V., Almerigi, J.B., Theokas, C., Phelps, E., Gestsdottir, S., Naudeau, S., Jelicic, H., Alberts, A., Ma, L., Smith, L.M., Bobek, D.L. (2005). Positive youth development, participation in community youth development 
programs, and community contributions of fifth grade adolescents: Findings from the firstwave of the 4-H Study of Positive Youth Development. Journal of Early Adolescence, 25, 17-71. https://doi.org/10.1177/0272431604272461

Lundy, L. (2007). Voice is not enough: Conceptualising Article 12 of the United Nations Convention on the Rights of the Child. British Educational Research Journal, 33(6), 927-942. https://doi.org/10.1080/01411920701657033

MAP-Works $^{\mathrm{TM}}$. (2014). The Foundation of MAP-Works Research and Theoretical Underpinnings of MAP-Works. EBI MAP-Works 2014. https://www.asc.dso.iastate.edu/sites/default/files/mapworks/MW\%20Foundations\%20-\%202014.pdf

McLeroy, K.R., Bibeau, D., Steckler, A., \& Glanz, K. (2004). An Ecological Perspective on Health Promotion Programs. Health Education Quarterly, 15(4), 351-377. https://doi.org/10.1177/109019818801500401

Moore-Cherry, N., Quin, S., \& Burroughs, N. (2015). Why students leave: Findings from qualitative research into student non-completion in higher education in Ireland. National Forum for the Enhancement of Teaching and Learning in Higher Education https://www.teachingandlearning.ie/publication/why-students-leave-findings-from-qualitative-research-intostudent-non-completion-in-higher-education-in-ireland/

National Youth Council of Ireland. (2018). Youth in Europe: What next? Structured dialogue cycle VI - Consultation Phase. Department of Children and Youth Affairs. https://www.youth.ie/documents/youth-in-europe-what-next-sd-cycle-viconsultation-report-summary/

Nelson, K., Duncan, M., \& Clarke, J. (2009). Student success: The identification and support of first-year university students at risk of attrition. Studies in Learning, Evaluation, Innovation and Development, 6(1), 1-15. https://eprints.qut.edu.au/28064 /

Olufisayo John-Akinola, Y., Gavin, A., O’Higgins, S.E., \& Nic Gabhainn, S. (2014). Taking part in school life: Views of children. Health Education, 114(1), 20-42. https://doi.org/10.1108/HE-02-2013-0007

O’Hara, M.C., Cunningham, A., Keighron, C., Allen, G., Caulfield, A., Duffy, C., Long, M., Mallon, M., Mullins, M., Tonra, G., Simkins, S., Hynes, L., O’Donnell., M., Byrne, M., Dinneen, S., \& the D1 Now Type 1 Diabetes Young Adult Study Group. (2017). Formation of a type 1 diabetes young adult patient and public involvement panel to develop a health behaviour change intervention: The D1 Now study. Research Involvement and Engagement, 3(21), 1 - 16. https://doi.org/10.1186/s40900-017-0068-9

O'Higgins, S., \& Nic Gabhainn, S. (2010). Youth participation in setting the agenda: Learning outcomes for sex education in Ireland. Sex Education, 10(4), 387 - 403. https://doi.org/10.1080/14681811.2010.515096

Ramsburg, L. (2007). Strive for success: A successful retention program for Associate of Science in Nursing students. Teaching and Learning in Nursing, 2(1), 12-16. https://doi.org/10.1016/j.teln.2006.10.005

Redmond, A. (2000). That was then, this is now: Change in Ireland 1949 - 1999. The Stationery Office, Dublin.

Redmond, B., Quinn, S., Devitt, C., Archbold, J. (2011). A qualitative investigation into the reasons why students exit from the first year of their programme at UCD. University College Dublin. https://www.ucd.ie/t4cms/Reasons\%20Why\%20Students\%20Leave.pdf

Ryan, M., \& Glenn., P. (2004). What do first-year students need most: Learning strategies instruction or academic socialisation? Journal of College Reading and Learning, 34(2), 4-28. https://doi.org/10.1080/10790195.2004.10850159

Sadowski, C., Stewart, M., \& Pediaditis, M. (2018). Pathway to success: Using students' insights and perspectives to improve retention and success for university students from low socioeconomic (LSE) backgrounds. International Journal of Inclusive Education, 22(2), 158-175. https://doi.org/10.1080/13603116.2017.1362048

Shaw, C., Brady, L.M., Davey, C. (2011). Guidelines for research with children and young people. National Children's Bureau Research Centre. https://childethics.com/library/other-literature/guidelines-for-research-with-children-and-youngpeople/

Singer, W. (2003). The role of the campus visits and summer orientation program in the modification of student expectations about college. Journal of College Orientation and Transition, 10(2), 52-59. https://doi.org/10.24926/jcotr.v10i2.2571

Thomas, L., Hill, M., O’Mahony, J., Yorke, M. (2017). Supporting student success: Strategies for institutional change. What Works? Student Retention \& Success programme. https://www.advance-he.ac.uk/knowledge-hub/supporting-studentsuccess-strategies-institutional-change

Tinto, V. (1993). Leaving college: Rethinking the causes and cures of student attrition (2nd ed.). University of Chicago Press.

Tinto, V. (2006). Research and practice of student retention; what next? Journal of College Student Retention, 8, 1-19. https://doi.org/10.2190/4YNU-4TMB-22DJ-AN4W

Tinto, V. (2017) Reflections on Student Persistence. Student Success, 8(2), 1-8. https://doi.org/10.5204/ssj.v8i2.376

Varnham, S., Olliffe, B., Waite, K., Cahill, A. (2018). Student engagement in university decision-making and governance: Towards a more systematically inclusive student voice. 2015-2016. Final Report https://studentvoiceaustralia.com/

Wallerstein, N.B., \& Duran, B. (2006). Using Community-Based Participatory Research to Address Health Disparities. Health Promotion Practice, 7(3), 312-323. https://doi.org/10.1177/1524839906289376

Yonghong, J. (2016). Attention to Retention: Exploring and addressing the needs of college students in STEM majors. Journal of Education and Training Studies, 4, 67-76. https://doi.org/10.11114/jets.v4i2.1147 


\section{Please cite this article as:}

Daniels, N., \& MacNeela, P. (2021). Students' views of the promoters and barriers to first year college persistence in Ireland: A partnership study. Student Success, 12(1), 56-71. https://doi.org/10.5204/ssj.1211

This article has been peer reviewed and accepted for publication in Student Success. Please see the Editorial Policies under the 'About' section of the Journal website for further information.

Student Success: A journal exploring the experiences of students in tertiary education.

(c) (i) Except where otherwise noted, content in this journal is licensed under a Creative Commons Attribution 4.0 International Licence. As an open access journal, articles are free to use with proper attribution. ISSN: 2205-0795 